\title{
MISCONCEPTIONS OF HIGH SCHOOL STUDENTS IN SALT HYDROLYSIS TOPIC USING A THREE-TIER DIAGNOSTIC TEST (TTDT)
}

\author{
Tri Prianti, Elfi Susanti VH, and Nurma Yunita Indriyanti* \\ Chemistry Education Study Program, Faculty of Teacher Training and Education, \\ Universitas Sebelas Maret \\ Jl. Ir. Sutami No. 36 A, Surakarta 57126, Central Java, Indonesia \\ * Correspondence: tel: 08156674227, email: nurma.indriyanti@staff.uns.ac.id
}

\begin{abstract}
This study aims to find out whether high school students in Surakarta have misconceptions in salt hydrolysis material and to find out which concept is the most misconception experienced by high school students in Surakarta in salt hydrolysis material. This study used a descriptive approach. Data collection techniques using data triangulation technique from the results of the Three-Tier Diagnostic Test (TTDT), formative tests, and interviews. The sample used in this study was determined using a purposive sampling technique. Based on the research conducted, high school students in Surakarta experienced misconceptions in salt hydrolysis material as much as $36.75 \%$, $35.94 \%$ Scientific knowledge, $15.63 \%$ lack of knowledge, and $10.90 \%$ error. Most misconceptions experienced by high school students in Surakarta on salt hydrolysis material occur in sub concepts: a) conclude the acid-base properties shown from salt solutions $(49.91 \%)$, b) calculate the $\mathrm{pH}$ of the salt solution (39.15), c) analyze the reaction salt hydrolysis $(37.21 \%)$, d) analyze the concept of hydrolysis that occurs in solution (35.98), e) determine the types of hydrolysis of salt (21.87\%).
\end{abstract}

Keywords: Misconception, salt hydrolysis, Three-Tier Diagnostic Test (TTDT)

\section{INTRODUCTION}

The 21st century marked by the rapid development of science and technology in the field of life in society, especially information and communication technology [1]. The needs of the 21 st century as it is now essential knowledge skills (cognitive) in-depth in the context of life regarding a problem, event, or event [2]. The rapid development of science and technology makes many countries compete with each other. The competition is to show the quality and consistency of a nation [3]. One of the things that can be prepared in the face of competition with people from other countries is to obtain sufficient education as a provision to compete in the community.

Education is a source of national progress that determines the competitiveness of a nation [3]. If people have a low level of education, it will be difficult for people to compete with people from other countries. At present, education in Indonesia has used the 2013 curriculum. The 2013 curriculum is a refinement of the Education Unit Level Curriculum (KTSP), which focuses on mastering contextual knowledge according to each region and environment. Learning process in 2013 curriculum is more focused on students or commonly called student-centered 
learning, which when learning takes place, students are more active and not teachercentered.

One of the obligatory subject in sciences is chemistry. Chemistry is a subject based on abstract concepts, so it is difficult to understand, especially when students are in a position to believe in something without seeing (believe without seeing) [4]. One of the difficulties students face in learning chemistry because learning chemistry is complex and abstract. Chemistry consists of three levels of representation, namely (a) macroscopic (everything that can be seen, touched, and felt), (b) submicroscopic (atoms, molecules, ions, and structures), and (c) symbolic (symbols, formulas, mathematical equations, graphs, molecular structures, diagrams, and others.) [5]. In addition, science is very close to a concept, which is a vital and essential concept in learning chemistry. The concept is a fundamental thing that is very instrumental in understanding a lesson [6]. Therefore, students usually try to understand and build their concepts to make it easier to learn. However, when students understand or build a concept by selecting information from the teacher, books, or the environment to improve their cognitive structure, students can make mistakes that will cause a concept error or commonly called misconception.

A misconception is a different understanding from the understanding accepted by the scientific community [7]. In learning chemistry, the concepts are arranged hierarchy so that if the basic concept experiences a misconception, it will cause a misconception in the next concept [8]. A misconception has meaning as an inaccurate concept, the use of wrong concepts, wrong classification of examples, chaos of different concepts, and hierarchical relationships of concepts that are not true [9]. In addition, misconception as a contradiction or incompatibility of concepts understood by someone with the concepts used by the experts of science concerned [10]. Therefore, a misconception is a problem faced by 21 st-century students. Students in the 21st century must have four competencies, namely, conceptual understanding, critical thinking, creative thinking, and collaboration, and communication [11]. Conceptual understanding is one important indicator to achieve the success of learning science [1]. Understanding the concept has a relationship with misconception, understanding the concept of mastery of concepts by the agreement of scientists, does not deviate, and does not cause other hypotheses that can cause cognitive conflict. In contrast, a misconception is a misconception with scientific understanding, which is accepted by experts.

Previous studies have shown that in salt hydrolysis material, students who have applied three chemical representations (macroscopicsubmicroscopic-symbolic).There are only 3\% that comprehended those three, students who are at the macroscopic-symbolic level of $97 \%$, and at $0 \%$ submicroscopic-symbolic levels [12]. These results indicate that students' scientific reasoning on hydrolysis material is still low. This research resulted in students' scientific reasoning ability at the level of no response by $1 \%$, non-normative $33 \%$, general descriptive $40 \%$, Bronsted causal $26 \%$, and Bronsted mechanistic $0 \%$. At the non-normative level, it means that there is an explanation, but it is not 
conceptual. This finding can be made possible due to misconceptions experienced by students. Besides, previous studies have found that $46 \%$ of students experience misconceptions about salt hydrolysis material [13]. Salt hydrolysis material was also detected using an interview sheet instrument, and it was found that $37.22 \%$ of students experienced misconceptions on this material [14].

Misconceptions can be identified using several methods, namely concept maps, written essay tests, interviews, class discussions, and diagnostic tests. A diagnostic test is a test used to find weaknesses (misconceptions) on a particular topic and get input on student responses to correct their weaknesses [8]. Several diagnostic tests have been used, namely diagnostic tests with multiple-choice instruments (ordinary multiple-choice tests), diagnostic tests with multiple-choice instruments accompanied by reasons, and diagnostic tests with multiple-choice instruments accompanied by choice of reasons [15].

In diagnostic tests with multiple-choice, instruments have some weaknesses. For instance, students who guess in answering questions contribute to the annoyance of variance and reduce the reliability of the test, the choice is chosen does not provide indepth insights about the basic ideas or concepts, students are forced to choose every answer from the choices that are so limited that students cannot express their ideas. It is challenging to write good multiple choice questions [16]. Diagnostic tests with multiple-choice instruments accompanied by reasons have weaknesses that require more time to think and write about the ideas they have, and the results obtained are challenging to evaluate. Assessors are needed to understand the reasons given by students [16], while the diagnostic test with multiple-choice instruments accompanied by choice of reasons has a weakness that is to find out the cause of the misconception still needed an interview to some students.

However, this type of diagnostic test with multiple-choice instruments accompanied by choice of reasons also has advantages that can be used to detect misconceptions, cover a variety of topics in a relatively short period, be objective in terms of assessment and be more reliable, easy and quick to assess, suitable for students who know the subject matter. However, their writing ability is low, suitable for item analysis. In contrast, an attribute can be determined, provides valuable diagnostic information, and is a viable alternative after interviews and other qualitative tools in measuring student understanding and in determining the distribution of misconceptions throughout the population [16].

This test has several types, namely two-tier multiple-choice and three tiers multiple choice. Two-tier Multiple-Choice is a multiplechoice test consisting of two layers or levels. In the first layer are questions and answer choices. Whereas in the second layer, in the form of reasons for the answers chosen in the first layer [15]. This test has a weakness that is not able to distinguish students who experience misconceptions, errors, do not understand the concept, and understand the concept, so it can not be ascertained whether students' mistakes are caused by misconceptions, errors, or lack of knowledge [17]. Three-tier diagnostic test (TTDT) has three 
layers. The first layer is a question, the second layer is a reason, and the third layer is a student's confidence in choosing an answer [15]. TTDT has the advantage of being able to distinguish between students who do not understand concepts, who experience misconceptions, and who already understand concepts. In the three-tier test can identify the existence of misconceptions that are supported by strong beliefs and not only because they answer incorrectly on the questions and reasons. Also, the Three-tier diagnostic test (TTDT) is proper for detecting the location of misconceptions [18].

The identification of the misconception was carried out in three high schools in Surakarta, where students from the three high schools had high cognitive abilities so that it was possible for many students to experience misconceptions. Research on misconceptions has been conducted on students who have high cognitive levels, and low cognitive levels, resulting in students who have high cognitive levels have more misconceptions than students who have low cognitive levels [19]. The identification of misconceptions in this study used a three-tier diagnostic test (TTDT) instrument that was more effective than the others. Thus, this research needs to be done to find out whether high school students in Surakarta experience misconceptions about salt hydrolysis material and subconcepts, which are the most misconceptions experienced by high school students in Surakarta on salt hydrolysis material.

\section{METHODS}

The study was conducted in three public high schools in Surakarta, where students had high cognitive abilities. This research was conducted in December 2018 until July 2019.The method used is a test method with a descriptive approach. In this study, the triangulation technique is used to verify data validity [20]. Triangulation techniques used in this study are the results of daily tests, test instruments, and interviews.

Three-Tier Diagnostic Test (TTDT) instruments in the form of 15 questions were administrated to six classes of 11 th grade natural science students with 189 students who had studied salt hydrolysis material.

Table 1. Analysis of Combination of Answers on One-Tier, Two-Tier, and Three-Tier

\begin{tabular}{lll}
\hline Tier Analysis & Categories & Response Types \\
\hline 1-tier analysis & Scientific knowledge & Correct response \\
& Misconception & Incorrect response \\
2-tier analysis & Scientific knowledge & Correct response + scientific explanation \\
& Error & incorrect response + scientific explanation \\
& Misconception & $\begin{array}{l}\text { Correct response + unscientific explanation } \\
\text { Incorrect response + unscientific explanation }\end{array}$ \\
& Scientific knowledge & Correct response + scientific explanation + sure \\
3-tier analysis & Correct response + scientific explanation + not sure \\
& & Incorrect response + scientific explanation + not sure \\
& & Correct response + unscientific explanation + not sure \\
& Incorrect response + unscientific explanation + not sure \\
& Error & Incorrect response + scientific explanation + sure \\
& Misconception & Correct response + unscientific explanation + sure \\
& Incorrect response + unscientific explanation + sure
\end{tabular}


The results of the answers obtained from the Three-Tier Diagnostic Test (TTDT) instruments were analyzed based on the provisions as in Table 1. Interview data were used as confirmatory, and the formative test results were used as member checks.Before conducting research, the instrument content validity test was checked through an expert judgment by two panels consisting of one high school teacher and one chemistry education lecturer. Then the reliability is tested by the Kuder-Ricardson 20 (KR-20) method.

\section{RESULTS AND DISCUSSION}

The identification of students' misconceptions in this study was based on the analysis of the combination of the results of students' answers, reasons, and students' beliefs in answering TTDT questions. Based on a combination of TTDT questions, it can be determined that students have understood concepts, not understood concepts, misconceptions, and errors. The questions used for this study were validated, and validity was obtained at 0.8 and reliability at 0.828 . This result shows that the question has a high-reliability value. The 189 students have been tested using the TTDT questions, and it is found that the level of understanding of students is as in table 2.

Table 2. Data on the Level of Understanding of 11th Grade Students on Salt Hydrolysis Material

\begin{tabular}{lc}
\hline $\begin{array}{l}\text { Level of Understanding } \\
\text { concept }\end{array}$ & $\begin{array}{c}\text { Percentage } \\
(\%)\end{array}$ \\
\hline Scientific knowledge & 35,97 \\
Lack of knowledge & 15,62 \\
Error & 10,93 \\
Misconception & 36,75 \\
\hline
\end{tabular}

For the category of students who Scientific knowledge, the highest percentage in the sub-concept determined the types of salt hydrolysis that was equal to $57.85 \%$. In the sub-concept about analyzing the concept of hydrolysis that occurs in solutions of $38.09 \%$. The subconcept concludes that the acid-base properties shown from the saline solution are $34.74 \%$. The percentage of students who understood the concepts in the sub-concept analyzed the salt hydrolysis reaction, which was $25.75 \%$. Then the subconcepts calculate the $\mathrm{pH}$ of the salt solution at $23.28 \%$.

Students who experience misconceptions about salt hydrolysis material occur in all sub-concepts. Percentage of misconceptions that occur in salt hydrolysis material, namely in the subconcept of analyzing the concept of hydrolysis that occurs in a salt solution of $35.80 \%$, subconcepts analyzing the salt hydrolysis reaction of $37.21 \%$, subconcepts calculate the $\mathrm{pH}$ of the salt solution by $39.15 \%$. The subconcept determines the type of salt hydrolysis is $21.69 \%$, while the subconcept concludes the acid-base properties shown from the salt solution that is equal to $49.91 \%$. It can be concluded that the biggest misconception experienced by students in salt hydrolysis material is in the sub conception of concluding the acid-base properties shown from the salt solution.

In the error category, students who entered the highest error category in the subconcept analyzed the salt hydrolysis reaction of $19.05 \%$. In the subconcepts, the $\mathrm{pH}$ of the salt solution is $13.23 \%$. Whereas in the subconcept, analyzing the concept of hydrolysis that occurs in a solution that is equal to 
$11.29 \%$. Then in the sub-concepts, determine the types of salt hydrolysis of $7.23 \%$, whereas the subconcept concludes the acid-base properties shown from the salt solution of $3.88 \%$.

Categories of lack of knowledge, the highest percentage is the subconcepts calculating the $\mathrm{pH}$ of the salt solution by $22.57 \%$. Then the subconcept analyzes the salt hydrolysis reaction of $17.81 \%$. In the subconcept, analyzing the concept of hydrolysis that occurs in solution is equal to $14.64 \%$. Subconcepts determine the types of salt hydrolysis that is equal to $12.17 \%$, whereas the subconcept concludes that the acid-base properties shown from the salt solution are $10.94 \%$.

In table 2, the overall misconception on salt hydroflysis material is $36.75 \%$. There are several categories of misconceptions, namely the low category $(0-30 \%)$, the medium category (31-60\%), and the high category (61-100\%) [21]. Thus, the 11th-grade students of Mathematics and Natural Sciences State High School in Surakarta experienced misconceptions in the medium category, namely, in the interval of $31-60 \%$.

In the subconcept in analyzing the concept of hydrolysis that occurs in salt solutions has a percentage of misconceptions of $35.80 \%$, which is included in the medium category. In this sub-concept, many students assume that ions derived from strong acids/bases can cause hydrolysis. Based on daily tests, students can determine the salt that can cause hydrolysis. However, during the interview in this sub-concept, students experience a misconception in the concept of hydrolysis in which the students interviewed answered that ions originating from strong acids/bases can cause hydrolysis reactions. The results of interviews with students in the sub-concept analyze the concept of hydrolysis that occurs in solutions, namely:

$\mathrm{P}: \mathrm{OK}$, then if there is $\mathrm{NaNO}_{2}$ dissolved in water, what causes the hydrolysis of the ion?

S: Na, Sodium

P: Why?

$\mathrm{S}$ : Because of $\mathrm{Na}$ from strong bases

$P$ : Does it mean that a strong base can cause hydrolysis?

S: Yes

In addition, based on the results of a three-tier diagnostic test, students assume that the hydrolysis reaction is a reaction in which the salt will decompose by water. The ion which comes from strong acid/base cannot cause hydrolysis, and hydrolysis reaction is a reaction where water will decompose by salt. This misconception is reinforced by the results of interviews with students, namely:

$P$ : Then, if, for example, there is question number 1 , which one is the reason?

S: 3

P: 3 ? sure?

S: hahaha

Problem number 1 is expected that students can determine the reaction that occurs in the dissolution of sodium benzoate salt with water. Reason number 3 in question number 1 states that if $\mathrm{C}_{6} \mathrm{H}_{5} \mathrm{COONa}$ is dissolved in water, $\mathrm{C}_{6} \mathrm{H}_{5} \mathrm{COONa}$ will be decomposed by water to produce its cations and anions. This finding shows that students experience a misconception that is salt is 
broken down into cations and anions by water. Previous research also found the same misconception, which states that the water is causing the separation of salt into cations and anions [22]. This analysis is not following the statement that hydrolysis is the reaction between water and salt cations or anions to produce $\mathrm{H}_{3} \mathrm{O}^{+}$and $\mathrm{OH}^{-}$ions due to the transfer of protons between ions and water [22]. Hydrolysis comes from the word hydro, which means water, and lysis means decomposition [23]. So salt hydrolysis is a breakdown of water by ions from salt.

Subconcepts analyzing the salt hydrolysis reaction has a percentage of misconceptions of $37.21 \%$, which misconceptions fall into the medium category. The misconception experienced by students in this subconcept is that students consider the species contained in the solution are species that are found in the product alone, and in the hydrolysis reaction, no ion is produced from strong acids/bases. Based on the results of daily tests, students can determine the hydrolysis reaction where ions derived from weak acids/bases can cause hydrolysis reactions. The results of the interview on the subconcept analyzed the salt hydrolysis reaction, namely:

$P$ : Do you think the hydrolysis reaction is a directional or back and forth reaction?

$\mathrm{S}$ : If hydrolysis is unidirectional

Also, the results of student interviews that support that the hydrolysis reaction occurs in one direction, namely:

$P$ : and then for number 2, what are the specifics if $\mathrm{NH}_{4} \mathrm{Cl}$ is added with water?

S: $\mathrm{NH}_{4}, \mathrm{H}^{+}, \mathrm{OH}^{-} \ldots$... well, that is that
The interview results show that according to students, the hydrolysis reaction is a reaction that goes one direction or irreversible so that the hydrolysis of the salt produced by the species contained in the product alone. In addition, students mentioned that if the hydrolysis reaction on $\mathrm{NH}_{4} \mathrm{Cl}$, the species contained in the solution is $\mathrm{NH}_{4}, \mathrm{H}^{+}$, $\mathrm{OH}^{-}$where there are no ions from strong acids, namely $\mathrm{Cl}^{-}$. This misconception is following the previous research, which states that students consider the hydrolysis reaction to occur irreversibly [24]. This explanation is not parallel to the correct concept that the hydrolysis reaction is reversible [25], and in the hydrolysis of the salt, there are still ions that come from strong acids/bases at the end of the reaction [14].

The subconcept calculates the $\mathrm{pH}$ of the salt solution as having a misconception percentage of $39.15 \%$ so that it falls into the medium category. Misconceptions experienced by students that students understand if the determination of the $\mathrm{pH}$ of a mixture of solutions using $\left[\mathrm{OH}^{-}\right]$which can be searched by finding the root of $\mathrm{K}_{w}$ divided by $\mathrm{K}_{\mathrm{a}}$ multiplied by the concentration of $\mathrm{CH}_{3} \mathrm{COONa}$. Based on daily tests, students incorrectly answered the $\mathrm{pH}$ value of the solution $\mathrm{Ca}\left(\mathrm{CH}_{3} \mathrm{COO}\right)_{2}$, and in the calculation of $\left[\mathrm{OH}^{-}\right]$, students used their salt concentration $\mathrm{Ca}\left(\mathrm{CH}_{3} \mathrm{COO}\right)_{2}$. In determining the $\mathrm{pH}$ of the solution $\mathrm{Ca}\left(\mathrm{CH}_{3} \mathrm{COO}\right)_{2}$ and in the calculation of $\left[\mathrm{OH}^{-}\right]$, the concentration used will affect the value of $\left[\mathrm{OH}^{-}\right]$ because the coefficient on the salt is $\mathrm{Ca}\left(\mathrm{CH}_{3} \mathrm{COO}\right)_{2}$ and the conjugate base of weak acids $\left(\mathrm{CH}_{3} \mathrm{COO}\right)$ are different. This answer is supported by the results of the interview, namely: 
P: How about number 3 ? How to calculate the $\mathrm{pH}$ ?

$\mathrm{S}$ : from the reason, miss?

$P$ : just according to you

$S$ : $K_{w}$ root per $K_{a}$ times the salt, $n(m o l)$ the salt

At number 3 , a hydrolysis reaction occurs in a mixture of $\mathrm{NaOH}$ and $\mathrm{CH}_{3} \mathrm{COOH}$ solutions whose volume and concentration are known. Students are expected to be able to determine the $\mathrm{pH}$ in the mixed solution.

Based on the results of the interview, students answered in determining the $\mathrm{pH}$ of the solution can be found by $\left[\mathrm{OH}^{-}\right]$, which can be searched by finding the root of $\mathrm{K}_{\mathrm{w}}$ divided by $K_{a}$ times the concentration of the salt. Previous research also obtained the same misconception in determining $\left[\mathrm{OH}^{-}\right]$is sought by calculating the $\mathrm{K}_{w}$ root divided by $\mathrm{K}_{\mathrm{a}}$ multiplied by the mol of salt [12]. This result is not following the correct concept, which is determining the $\mathrm{pH}$ can be found with $\left[\mathrm{OH}^{-}\right]$, which can be searched by finding the root of $\mathrm{K}_{\mathrm{w}}$ divided by $\mathrm{K}_{\mathrm{a}}$ multiplied by the concentration of the conjugate base of weak acid [12]. Misconceptions in subconcepts determine the types of salt hydrolysis, having a misconception percentage of $21.87 \%$, which is included in the low category. In this subconcept, students experience misconceptions by assuming that ions derived from weak acids and weak bases cannot cause hydrolysis. This is consistent with the results of the interviews obtained, namely:

$\mathrm{P}$ : OK, if in question number 4 , there are some $\mathrm{CH}_{3} \mathrm{COOK}, \mathrm{NH}_{4} \mathrm{Cl}, \mathrm{CH}_{3} \mathrm{COONH}_{4}$, and $\mathrm{K}_{2} \mathrm{SO}_{4}$ salts, which cannot cause hydrolysis is?

$\mathrm{S}$ : which is 3
$\mathrm{P}$ : which 3 is $\mathrm{CH}_{3} \mathrm{COONH}_{4}$, because?

$S$ : because of weak acids and weak bases

This response shows that students experience misconceptions by answering $\mathrm{CH}_{3} \mathrm{COONH}_{4}$ salt can not cause hydrolysis. Students assume that salt derived from weak acids and weak bases cannot cause hydrolysis, and salt derived from strong acids and bases can cause hydrolysis. This misconception is by the misconception that has been found previously, namely salts derived from strong acids and strong bases are perfectly hydrolyzed salts [14]. The more difficult it is to remove protons from the acid, and the easier it is for anions or their conjugate bases to attach protons from water (meaning hydrolysis) [26].

Misconceptions in subconcepts concluded the acid-base properties shown from salt solutions had a percentage of $49.91 \%$ included in the misconception in the medium category. The most misconception in this subconcept is the determination of the acidbase properties of a solution because it can change the color of litmus paper. Based on the results of daily tests, students can determine the acid-base properties of the solution. Based on the results of interviews conducted, namely:

$P$ : OK, then number 10 , some solutions were tested using litmus paper, which one do you think is alkaline?

S: The $\mathrm{CH}_{3} \mathrm{COOK}$

$\mathrm{P}$ : Why is $\mathrm{CH}_{3} \mathrm{COOK}$ ?

$S$ : Because it changed red litmus paper to blue.

This analysis shows that students experience misconceptions by assuming the alkaline nature of a salt solution is determined 
because it can blue paper litmus red. This misconception is following previous research, which states that the rate of change of litmus paper can be used as information to determine the strength of acid [27]. This result is not suitable for the concept that litmus paper is an indicator to determine the acid/base properties of a solution. So litmus paper is not the reason the solution can be acidic/basic. The acidic nature of a salt solution is because the ions from the salt can cause hydrolysis, which will produce $\mathrm{H}^{+}$or $\mathrm{OH}^{-}$ions so that the solution can be acidic or basic [14].

Based on the discussion above, in this study, it was found that a misconception experienced by students is salt decomposed into cations and anions by water. Hydrolysis reaction occurs irreversibly. Determination of the $\mathrm{pH}$ of the solution can be sought by $\left[\mathrm{OH}^{-}\right]$, which can be searched by finding the root of $\mathrm{Kw}$ divided by $\mathrm{Ka}$ times the concentration of the salt. Salts derived from weak acids and weak bases cannot cause hydrolysis, and salts derived from strong acids and bases can cause hydrolysis. The alkaline nature of a salt solution is determined because it can blue red litmus paper.

\section{CONCLUSION}

High school students in Surakarta experienced misconceptions on salt hydrolysis material is about $36.75 \%$, 35.94\% students had a scientific knowledge, $15.63 \%$ lack of knowledge, and $10.90 \%$ error. The most misconceptions experienced by high school students in Surakarta on salt hydrolysis material occurred in subconcepts: a) concluded the acid-base properties shown from the salt solution $(49.91 \%)$, b) calculated the $\mathrm{pH}$ of the salt solution (39.15\%), c) analyzed the reaction salt hydrolysis $(37.21 \%)$, d) analyze the concept of hydrolysis that occurs in solution $(35.98 \%)$, e) determine the types of salt hydrolysis $(21.87 \%)$.

\section{ACKNOWLEDGMENT}

The author thanks the principals of state high school in Surakarta for the permission given to the author to carry out research.

\section{REFERENCES}

[1] Y. Yuliati, "Miskonsepsi Siswa pada Pembelajaran IPA serta Remediasinya," J. Chem. Inf. Model., vol. 2, no. 2, pp. 50-58, 2017, DOI:10.1017/CBO9781107415324.004.

[2] H. Murniayudi, A. Mustadi, \& M. A. Jerusalem, "Reciprocal teaching: Sebuah inovasi pembelajaran abad 21 untuk meningkatkan pemahaman konsep mahasiswa PGSD," Prem. Educ. J. Pendidik. Dasar dan Pembelajaran, vol. 8, no. 2, p. 173, 2018, DOI: $10.25273 /$ pe.v8i2.3308.

[3] K. Shulamit \& E. Yossi, Development of E-Learning environments combining learning skills and science and technology content for junior high school. Procedia Social and Behavioral Sciences. vol.11, pp 175-17,2011 DOI:10.1016/j.sbspro.2011.01.056

[4] M. Stojanovska, V. M. Petruševski, \& B. Šoptrajanov, "Study of the Use of the Three Levels of Thinking and Representation," Contrib. Sect. Nat. Math. Biotech. Sci., vol. 35, no. 1, pp. 37-46, 2017,

DOI:10.20903/csnmbs.masa.2014.35.1.52.

[5] A. H. Johnstone, "Teaching of Chemistry -Logical or Psychological?," Chem. Educ. Res. Pract. Eur. Educ. Res. Pr. Eur, vol. 1, no. 1, pp. 9-15, 2000. DOI:10.1039/A9RP90001B 
[6] P. Medina, "Analisis Miskonsepsi Siswa kelas $\mathrm{X}$ pada Materi Larutan Elektrolit dan Non Elektrolit serta Reaksi Oksidasi dan Reduksi dalam Pembelajaran Kimia di SMAN 10 Kota Padang," J. Residu, vol. 1, no. 1, pp. 73-84, 2017.

[7] M. B. Nakhleh, "Why some students don't learn chemistry: Chemical misconcep-tions," J. Chem. Educ., vol. 69 , no. 3, pp. 191-196, 1992,

DOI: 10.1021/ed069p191.

[8] Suwarto, Pengembangan Tes Diagnostik dalam Pembelajaran (Panduan Praktis Bagi Pendidik dan Calon Pendidik). Yogyakarta: Pustaka Pelajar, 2017.

[9] P. Suparno, Miskonsepsi dan Perubahan Konsep dalam Pendidikan Fisika. Jakarta: Grasindo, 2005.

[10] H. D. Barke, A. Hazari, \& S. Yitbarek, Sileshi. Misconceptions in Chemistry Addressing Perceptions in Chemical Education, Berlin: Springer-Verlag Berlin Heidelberg,2009.

DOI: 10.1007/978-3-540-70989-3

[11] C. C. Morocco, C. M. Aguilar, C. Bershad, A. W. Kotula, \& A. Hindin, Supported Literacy for Adolescents: Transforming Teaching and Content Learning for the Twenty-First Century. London : wiley2012.

DOI: $10.1002 / 9781118269350$

[12] F. Widyasari, N. Y. Indriyanti, \& S. Mulyani," The Effect of Chemistry Learning with PjBL and PBL Model Based on Tetrahedral Chemistry Representation in term of Student's Creativity, JKPK (Jurnal Kimia dan Pendidikan Kimia), vol. 3, no. 2,pp,93102, 2018.

DOI:10.20961/jkpk.v3i2.16638

[13] D. Amelia, M. Marheni, \& N. Nurbaity, "Analisis Miskonsepsi Siswa Pada Materi Hidrolisis Garam Menggunakan Teknik Cri (Certainty of Response Index) Termodifikasi," JRPK J. Ris. Pendidik. Kim., vol. 4, no. 1, pp. 260 266, 2014, DOI: 10.21009/jrpk.041.05.
[14] U. L. Hidayah, K. I. Supardi, W. Sumarni, \& M. A. N. Purworejo, "Penggunaan Instrumen Lembar Wawancara Pendukung Tes Diagnostik Pendeteksi Miskonsepsi untuk Analisis Pemahaman Konsep Buffer-Hidrolisis," J. Inov. Pendidik. Kim., vol. 12, no. 1, 2018.

[15] D. Kaltakci-Gurel, A. Eryilmaz, \& L. C. McDermott, "Development and application of a four-tier test to assess preservice physics teachers' misconceptions about geometrical optics," Res. Sci. Technol. Educ., vol. 35, no. 2, pp. 238-260, 2017,

DOI:10.1080/02635143.2017.1310094.

[16] E. Widiyoko, Teknik Penyusunan Instrumen Penelitian. Yogyakarta: Pustaka Pelajar, 2012.

[17] D. Kaltakçi \& N. Didiç, "Identification of pre-service physics teachers' misconceptions on gravity concept: A study with a 3-tier misconception test," AIP Conf. Proc., vol. 899, pp. 499-500, 2007, DOI: 10.1063/1.2733255.

[18] A. C. Sugiarti, "The Development Of Three Tier Diagnostic Test To Identify Student Misconception In Chemical Bonding On 10 Th Grader" Unesa Journal of Chemical Education, vol. 4, no. 3, pp. 456-465, 2015.

[19] S. Sadhu, M. T. Tima, V. P. Cahyani, A. F. Laka, D. Annisa, \& A. R. Fahriyah, "Analysis of acid-base misconceptions using modified certainty of response index (CRI) and diagnostic interview for different student levels cognitive," Int. J. Sci. Appl. Sci. Conf. Ser., vol. 1, no. 2 , p. 91,2017 ,

DOI: 10.20961/ijsascs.v1i2.5126.

[20] Sugiyono, Memahami Penelitian Kualitatif. Bandung: Alfabeta, 2016.

[21] T. I. Putro, S. R. D. Ariani, \& S. Yamtinah, "Identification of Students Misconception Using Two-Tier Diagnostic Test Completed with Certainty of Response Index (CRI) on Topic Partial Salt Hydrolysis," JKPK ( Jurnal Kimia dan Pendidikan Kimia), vol. 4, no. 2, pp,123-133,2019.

DOI:10.20961/jkpk.v4i2.34235 
[22] N. F. Maratusholihah, R. Sri, \& F. Fauziatul, "Analisis miskonsepsi siswa sma pada materi hidrolisis garam dan larutan penyangga," J. Pendidik., vol. 2, no. 7, pp. 919-926, 2017, DOI: 10.17977/jptpp.v2i7.9645.

[23] J. Brady, Kimia Universitas. Jakarta: Erlangga, 1994.

[24] K. Orwat, P. Bernard, \& A. MigdałMikuli, "Alternative conceptions of common salt hydrolysis among uppersecondaryschool students," J. Balt. Sci. Educ., vol. 16, no. 1, pp. 64-76, 2017.
[25] R. Petrucci, General Chemistry: Principles adn Modern Applications, 4th. Ed. New York: Macmilan Publishing Company, 1985.

[26] J. Rosenberg, College Chemistry: Tenth Edition (Schaum's Outlines). London: McGraw-Hill Education, 2013

[27] F. D. Mubarokah, S. Mulyani, \& N. Y. Indriyanti, "Identifying Students' Misconceptions of Acid-Base Concepts Using a Three-Tier Diagnostic Test: A Case of Indonesia and Thailand," Journal of Turkish Science Education, vol. 15, pp. 51-58, 2018.

DOI: 10.12973/tused.10256a 